\title{
Soil water repellence increased early wheat growth and nutrient uptake
}

\author{
S. G. H. Yeap $\cdot$ R. W. Bell $\cdot$ C. Scanlan $\cdot$ \\ K. Stefanova $\cdot$ R. Harper $\cdot$ S. Davies
}

Received: 19 September 2021 / Accepted: 17 December 2021 / Published online: 22 January 2022

(C) Crown 2022

\begin{abstract}
Purpose Soil water repellence causes uneven soil wetting which can constrain dryland crop and pasture establishment and yield. The same processes are likely to affect nutrient availability from soil and fertiliser, but the effects of repellence on crop growth and nutrition per se have seldom been reported. Here, we investigated early wheat (Triticum aestivum cv. Mace) growth and nutrient uptake responses to repellence.

Methods Wheat was furrow-sown in severely repellent sandy loam soil (with a wettable furrow base to allow for germination) or completely wettable soil, under uniform plant density and variable topsoil thickness (20 or $100 \mathrm{~mm}$ ) and fertiliser band placement (below or away from the seed). Tiller number, shoot dry matter, shoot $\mathrm{N}$ concentration, total
\end{abstract}

Responsible Editor: W Richard Whalley

S. G. H. Yeap $(\bowtie) \cdot$ R. W. Bell · R. Harper

SoilsWest, Centre for Sustainable Farming Systems,

Future Food Institute, Murdoch University, Murdoch,

WA 6150, Australia

e-mail: s.yeap@murdoch.edu.au

R. W. Bell

e-mail: r.bell@murdoch.edu.au

R. Harper

e-mail: r.harper@murdoch.edu.au

C. Scanlan

Department of Primary Industries and Regional nutrient uptake, and root length density (RLD) were determined.

Results Contrary to expectations, repellence significantly increased tiller number (by up to 2 tillers per plant), shoot dry matter (by $82 \%$ ), shoot $\mathrm{N}$ concentration (by $0.3 \% \mathrm{~N}$ ), and total nutrient uptake (by $87 \%$ ) at 51 days after sowing, regardless of topsoil thickness and fertiliser placement. In the furrow, RLD of repellent treatments was also nearly double that in wettable treatments when fertiliser was banded below the seed. Results suggest that preferential soil wetting of the furrow in repellent treatments favoured plant nutrient uptake under regular but low water supply.

Conclusion We conclude that for water-repellent soils with limited water supply, water harvesting techniques such as furrow sowing and banding wetting agents could boost water and nutrient uptake and early crop growth.

Development, Northam, WA 6401, Australia

e-mail: craig.scanlan@dpird.wa.gov.au

K. Stefanova

SAGI, School of Molecular and Life Sciences, Curtin

University, Bentley, WA 6102, Australia

e-mail: katia.stefanova@curtin.edu.au

S. Davies

Department of Primary Industries and Regional

Development, Geraldton, WA 6530, Australia

e-mail: stephen.davies@dpird.wa.gov.au 
Keywords Furrow sowing - Root growth $\cdot$ Sandy loam $\cdot$ Water harvesting

\section{Introduction}

Soil water repellence is a constraint to crop and pasture production in many parts of the world (Smettem et al. 2021). In Australia, production losses due to repellence are estimated to be $\$ 251$ million per year (Herbert 2009), with 9.9 million hectares of arable land at moderate to high risk of repellence in southwestern Western Australia alone (van Gool 2016). Repellence commonly develops in sands with low clay content $(<5 \%$; Harper and Gilkes 1994), generally within the upper $10 \mathrm{~cm}$ of the profile due to the decomposition of plant and fungal matter (Doerr et al. 2000; Franco et al. 2000), resulting in the accumulation of hydrophobic organic compounds on or between soil particles (Bisdom et al. 1993; Mainwaring et al. 2013; Morley et al. 2005). However, repellence has also been reported across a range of clay contents under Eucalyptus globulus plantations (0.8-18.0\%; Walden et al. 2015) and Eucalyptus astringens woodland (18-22\%; McGhie and Posner $1980)$, and heavy clay soils under grass (>60\%; Dekker and Ritsema 1996).

Repellence causes uneven water infiltration rates (Li et al. 2018; Wang et al. 2000) which accentuate runoff and soil erosion (Shakesby et al. 2000; Witter et al. 1991), and the development of unstable wetting patterns and preferential flow paths which can cause water and nutrients to bypass a large volume of the plant root zone (Bauters et al. 1998; Dekker and Ritsema 1996; Ritsema and Dekker 1994). As such, nutrient leaching is a known risk in water-repellent soils (Blackwell 2000; Hendrickx et al. 1993). Due to these hydrological processes, crop germination on water-repellent sandy soil is often delayed and staggered, and this can lead to lower grain yields (Bond 1972; Roper et al. 2015). However, apart from its adverse effect on germination, the effects of repellence on soil nutrient availability and crop growth and nutrition per se have seldom been reported.

In semi-arid cropping systems, reduced soil water storage and moisture availability due to uneven wetting can adversely affect crop growth (Doerr et al. 2000; Kramers et al. 2005; Li et al. 2019), but the persistence of dry soil may also limit soil nutrient bioavailability (Roper et al. 2015). Li et al. (2019) showed that an increase in the persistence of repellence in sandy loam soils was associated with decreased growth, yield, and water use efficiency in summer maize under controlled irrigation, and attributed the adverse effect to a decrease in soil water availability and impeded root water uptake, but they did not consider effects on crop nutrition. Significant preferential flow may also result in accelerated leaching of nutrients after substantial rainfall (i.e., under saturated flow; Seyfried and Rao 1987), causing nutrients such as mineral $\mathrm{N}$ to be transported beyond the root zone (Angus 2001; Liao et al. 2006), particularly in sandy soils which have a low retention capacity (Lehmann and Schroth 2003). However, in contiguous zones where dry patches persist, soil organic matter and nutrients therein may be protected from mineralisation and leaching (Goebel et al. 2011; Hoyle 2013). Other processes including enhanced runoff and soil erosion due to repellence can also result in significant losses in $\mathrm{P}$, especially after fertiliser spreading (McDowell et al. 2020; Müller et al. 2018; Simmonds et al. 2016). Hence, while there are several ways by which repellence effects on soil water and nutrient availability may limit crop growth and nutrition, there has been little direct examination of the mechanisms.

The potential for repellence to conserve soil water by reducing evaporation from the soil surface is wellknown (Bachmann et al. 2001; Rye and Smettem 2017). Reduced evaporation has been attributed to a reduction in upward capillary movement of water (DeBano 1981) and the diversion of water to the subsoil via preferential flow pathways (Ritsema and Dekker 1994), which may enhance a crop's subsurface water supply (Kirkegaard et al. 2007). Compared to wettable soil surface treatments, significant net reductions in water evaporation in treatments with a repellent soil surface have also been found to significantly increase the shoot and root growth of young chickpea (Cicer arietinum) plants (Gupta et al. 2015). Similarly, the addition of a subsurface water-repellent sand layer beneath wettable soil also increased plant height and root length of lettuce (Lactuca sativa) compared to wettable control treatments due to a reduction in water seepage below the root zone and an increased tolerance of plants to water stress (Salem et al. 2010). Hence, repellence may help retain water longer and 
allow roots more time to acquire it (Alazawi 2015; Kianmeher et al. 2016; Ruthrof et al. 2019).

Based on the effect of repellence on soil water availability, it was hypothesised that early plant nutrient uptake would be impeded on water-repellent sandy soils if plant-available water supply and root growth were limited. Such an effect would also be greater in soils with a thicker water-repellent layer, presumably due to a reduction in the soil volume accessed by roots for nutrient acquisition (Cornforth 1968). In this study, responses of wheat growth and nutrient uptake to severe repellence were assessed over 51 days under controlled glasshouse conditions and uniform plant density, with variable topsoil thickness and fertiliser band placement.

\section{Methodology}

Preparation of growing containers

Wheat cv. Mace was grown over 51 days in $27 \mathrm{~L}$ containers in a glasshouse at Murdoch University, Western Australia (3204'02.30" S 115 $50^{\prime} 20.21^{\prime \prime}$ E) to investigate early wheat growth and nutrition responses to:

a. soil water repellence (wettable and severely repellent topsoil),

b. topsoil thickness (20 and $100 \mathrm{~mm}$ ), and

c. fertiliser placement $(50 \mathrm{~mm}$ below the seed and $100 \mathrm{~mm}$ away from the seed row at the same depth).

The 8 treatment combinations were replicated three times and arranged in a completely randomised design. Online Resource 1 illustrates the design of the growing containers.

Severely water-repellent topsoil (molarity of ethanol droplet, MED, value of 3.4 M; King 1981) was collected from the $0-10 \mathrm{~cm}$ depth of a gravelly sandy loam duplex soil (Ferric Chromosol, Australian Soil Classfication (ASC); Isbell 2016) in Kojonup, West-

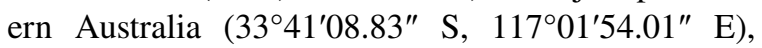
with wettable subsoil (MED value of $0.0 \mathrm{M}$ ) collected from the 20-30 cm depth of a grey deep sandy duplex soil (Grey Bleached-Ferric Kandosol, ASC) at Meckering $\left(31^{\circ} 37^{\prime} 38.22^{\prime \prime} \mathrm{S}, 116^{\circ} 52^{\prime} 16.53^{\prime \prime}\right.$ E). Properties of the sieved topsoil and subsoil $(\leq 2 \mathrm{~mm})$ used for the experiment are listed in Table 1.

All soils were air-dried in glasshouse and sieved $(<2 \mathrm{~mm})$. To prepare wettable topsoil (MED 0.0 M), repellent topsoil was treated with approximately $20 \mathrm{ml}$ of $12.5 \% \mathrm{v} / \mathrm{v}$ solution of commercial soil wetting agent SE14TM (SACOA Pty Ltd) per kilogram of soil in a cement mixer. Holes were drilled in each container to allow for drainage, with shade cloth placed along the bottom to prevent soil spillage. Topsoil (0-20 or 0-100 $\mathrm{mm}$ depth) and subsoil (20-200 or $100-200 \mathrm{~mm}$ depth, respectively) were layered and compacted in each container to a total depth of $200 \mathrm{~mm}$ and a final bulk density of $c a .1 .5 \mathrm{~g} /$ $\mathrm{cm}^{3}$. Fertiliser was banded at $70 \mathrm{~mm}$ depth $(20 \mathrm{~mm}$ width $\times 5 \mathrm{~mm}$ depth) either below or $100 \mathrm{~mm}$ away from the seeding row at the following rates $(\mathrm{mg} / \mathrm{kg})$ : $60 \mathrm{~N}, 25 \mathrm{P}, 70 \mathrm{~K}, 6 \mathrm{Mg}, 49 \mathrm{~S}, 0.5 \mathrm{Zn}, 0.1 \mathrm{~B}, 0.3 \mathrm{Mn}$, and $0.1 \mathrm{Cu}$. The volume of soil enriched with fertiliser was $c a .40 \mathrm{~cm}^{3}$.

Table 1 Baseline properties of topsoil and subsoil $(<2 \mathrm{~mm})$ used in treatment containers. Soils were analysed by the methods of Rayment and Lyons (2011)

\begin{tabular}{lll}
\hline Soil properties & Topsoil & Subsoil \\
\hline $\mathrm{pH}\left(\mathrm{CaCl}_{2}\right)$ & 5.1 & 5.0 \\
Organic carbon $(\mathrm{g} / \mathrm{kg})$ & 35.3 & 2.1 \\
Electrical conductivity $(\mathrm{dS} / \mathrm{m})$ & 0.04 & 0.02 \\
$\mathrm{NH}_{4}-\mathrm{N}(\mathrm{mg} / \mathrm{kg})$ & 6 & $<1$ \\
$\mathrm{NO}_{3}-\mathrm{N}(\mathrm{mg} / \mathrm{kg})$ & 12 & $<1$ \\
Colwell P $(\mathrm{mg} / \mathrm{kg})$ & 65 & 14 \\
Colwell K $(\mathrm{mg} / \mathrm{kg})$ & 151 & 20 \\
Cation exchange capacity $(\mathrm{cmol}(+) / \mathrm{kg})$ & 5.82 & 1.09 \\
Exchangeable Ca $(\mathrm{cmol}(+) / \mathrm{kg})$ & 4.55 & 0.79 \\
Exchangeable $\mathrm{Mg}(\mathrm{cmol}(+) / \mathrm{kg})$ & 0.61 & 0.15 \\
Exchangeable K $(\mathrm{cmol}(+) / \mathrm{kg})$ & 0.36 & 0.04 \\
Exchangeable Na $(\mathrm{cmol}(+) / \mathrm{kg})$ & 0.09 & $<0.01$ \\
Exchangeable $\mathrm{Al}(\mathrm{cmol}(+) / \mathrm{kg})$ & 0.21 & 0.10 \\
Extractable S $(\mathrm{mg} / \mathrm{kg})$ & 7.1 & 1.7 \\
Extractable B $(\mathrm{mg} / \mathrm{kg})$ & 0.54 & 0.19 \\
Extractable Cu $(\mathrm{mg} / \mathrm{kg})$ & 0.37 & 0.30 \\
Extractable Fe $(\mathrm{mg} / \mathrm{kg})$ & 23.3 & 18.1 \\
Extractable $\mathrm{Mn}(\mathrm{mg} / \mathrm{kg})$ & 4.01 & 0.96 \\
Extractable $\mathrm{Zn}(\mathrm{mg} / \mathrm{kg})$ & 1.33 & 0.27 \\
Sand $(\mathrm{g} / \mathrm{kg})$ & 694 & 831 \\
Silt $(\mathrm{g} / \mathrm{kg})$ & 133 & 53 \\
Clay $(\mathrm{g} / \mathrm{kg})$ & 173 & 116 \\
\hline & & \\
& &
\end{tabular}


Sixteen wheat seeds were sown in a wettable furrow, equivalent to a plant density of 133 plants $/ \mathrm{m}^{2}$, with approximately $300 \mathrm{~g}$ of wettable topsoil used for the seeding row ( $20 \mathrm{~mm}$ width $\times 20 \mathrm{~mm}$ depth) in repellent treatments to ensure uniform germination. Plants were reduced to a plant density of 15 plants per container (equivalent to 125 plants $/ \mathrm{m}^{2}$ ) and were hand watered every 2 days, with $500 \mathrm{ml}(4.2 \mathrm{~mm})$ of tap water sprinkled over the whole soil surface over a duration of $5 \mathrm{~min}(\mathrm{ca} .50 \mathrm{~mm} / \mathrm{h}$; equivalent rainfall intensity at a $63.2 \%$ annual exceedance probability for a paddock at Kojonup). A total of $105 \mathrm{~mm}$ water was applied over 50 days (final irrigation at 50 DAS), but the watering did not cause drainage from the base of any container. By comparison, the mean total amount of rainfall over 51 days during May and June is $106 \mathrm{~mm}$ at Kojonup (Bureau of Meteorology). The glasshouse had an average day air temperature of $19^{\circ} \mathrm{C}$ and relative humidity of $36 \%$, which would create higher evaporative demand relative to the field at Kojonup (i.e., average maximum day temperature of $17{ }^{\circ} \mathrm{C}$ and relative humidity of $56 \%$ between May and June).

A completely randomised design (CRD) was used for the positioning of the containers with three replicates for each treatment combination on one bench in the glasshouse.

\section{Plant and soil water measurements}

Wheat tillers were counted at 46 days after sowing (DAS) and whole shoots were harvested at 51 DAS and oven-dried at $60{ }^{\circ} \mathrm{C}$ for 4 days to determine shoot dry matter. Nutrient concentrations in whole shoot samples were analysed using standard methods (Rayment and Lyons 2011), with total nutrient uptake calculated from shoot dry matter. Roots were extracted at harvest in the furrow and inter-row at the $0-5,5-10,10-15$, and $15-20 \mathrm{~cm}$ depths, using a $20 \mathrm{~cm}$ long, $6.2 \mathrm{~cm}$ diameter coring tube (i.e., $151 \mathrm{~cm}^{3}$ sample volume). Root samples were rinsed in water, stored in vials containing $50 \% \mathrm{v} / \mathrm{v}$ ethanol solution at $4{ }^{\circ} \mathrm{C}$. Root length $(\mathrm{cm})$ was assessed using WinRHIZO version 2005c (Regent Instruments Inc., Quebec, Canada) with results presented as root length per cubic centimetre of soil (i.e., root length density, $\mathrm{RLD}, \mathrm{cm} / \mathrm{cm}^{3}$ ).

In situ volumetric soil water content in the furrow and inter-row at $0-5$ and $10-15 \mathrm{~cm}$ depths were also measured at harvest using a handheld MPM160 (ICT International Pty Ltd, Armidale, NSW) moisture probe meter.

\section{Statistical analyses}

Linear mixed models (LMM) were used to determine the main and interaction effects of the factors: soil water repellence (SWR), topsoil thickness (TT) and fertiliser placement (FP) on wheat growth and nutrient uptake. Each factor is presented with two levels: SWR (wettable and repellent), TT (20 and $100 \mathrm{~mm}$ ), and FP (below and away). The growth response variables included tiller number per plant and shoot dry matter (g/plant). The nutrition response variables included shoot $N$ concentration (\%), total uptake of $\mathrm{N}, \mathrm{P}, \mathrm{K}, \mathrm{Ca}, \mathrm{Mg}$, and $\mathrm{S}$ in $\mathrm{mg} / \mathrm{plant}$, and total uptake of $\mathrm{Na}, \mathrm{B}, \mathrm{Cu}, \mathrm{Fe}, \mathrm{Mn}$, and $\mathrm{Zn}$ in $\mu \mathrm{g} / \mathrm{plant}$. The models for all response variables included the described treatment structure with three factors and their interactions, fitted as fixed.

Repeated measures techniques were used for the response variables where depth measurements were taken. The models included the same treatment structure, as described above, and additionally a variance-covariance structure was fitted to the interaction random term Container.Depth to account for the correlated nature of the measurements in depth within each container. Therefore, the containers for Container were assumed to be independent and identity correlation structure was assumed while the depths for Depth within each container were assumed to be correlated. For response variables, separate models were fitted for the furrow and for the inter-row. Two types of covariance structures were used, based on the number of measurements in depth: uniform heterogeneity (for Soil water) and power heterogeneous (for Root length).

Assumptions for normality and homogeneity of the error variances were assessed and, where the assumptions were violated, data were transformed using a $\log _{10}$ transformation. To investigate key relationships between soil water at harvest, wheat shoot growth and nutrition parameters in wettable and repellent treatments, correlation analysis was conducted. The relative strength of Pearson's $r$ correlation coefficient was classified as follows: weak $(\mathrm{r} \leq 0.39)$, moderate $(0.40 \leq \mathrm{r} \leq 0.59)$, strong $(0.60 \leq \mathrm{r} \leq 0.79)$, and very strong $(0.80 \leq \mathrm{r} \leq 1.00)$. 
All statistical analyses were conducted using the statistical environment R ( $R$ Core Team, 2020), GenStat Ed.20 (VSN International, 2020) and ASReml R v.4 (VSN International, 2020).

\section{Results}

Wheat shoot growth

An interaction between repellence and topsoil thickness was observed for wheat shoot dry matter (Table 2). Average dry matter per plant (51 DAS) was $82 \%$ greater in repellent treatments than in wettable treatments (Fig. 1). Although topsoil thickness did not affect dry matter in repellent treatments, dry
Table 2 Linear mixed model ( $P$ values) for main effects and interactions between soil water repellence (SWR), topsoil thickness (TT), and fertiliser placement (FP) on wheat shoot dry matter, nutrition, root length density (RLD), and volumetric soil water content (51 DAS)

\begin{tabular}{lrrrrrrr}
\hline Source of variation & \multicolumn{1}{l}{ SWR } & TT & FP & SWR $\times$ TT & SWR $\times$ FP & TT $\times$ FP & SWR $\times$ TT $\times$ FP \\
\hline Shoot dry matter & $<0.001$ & $<0.001$ & $<0.001$ & 0.005 & 0.027 & 0.134 & 0.062 \\
Shoot N concentration & $<0.001$ & 0.373 & 0.201 & 0.424 & 0.191 & 0.937 & 0.581 \\
Total N uptake & $<0.001$ & $<0.001$ & 0.001 & 0.008 & 0.017 & 0.117 & 0.080 \\
Total P uptake & $<0.001$ & $<0.001$ & $<0.001$ & 0.535 & 0.003 & 0.565 & 0.597 \\
Total K uptake & $<0.001$ & 0.018 & $<0.001$ & $<0.001$ & 0.002 & 0.045 & 0.027 \\
Total Ca uptake & $<0.001$ & 0.005 & 0.016 & 0.004 & 0.009 & 0.003 & 0.002 \\
Total Mg uptake & $<0.001$ & 0.001 & 0.068 & 0.032 & 0.015 & 0.031 & 0.096 \\
Total S uptake & $<0.001$ & $<0.001$ & $<0.001$ & 0.220 & 0.824 & 0.688 & 0.362 \\
Total Na uptake & $<0.001$ & $<0.001$ & 0.471 & 0.734 & 0.497 & $<0.001$ & 0.266 \\
Total B uptake & 0.001 & 0.001 & $<0.001$ & 0.935 & 0.263 & 0.670 & 0.760 \\
Total Cu uptake & $<0.001$ & $<0.001$ & 0.036 & 0.023 & 0.067 & 0.229 & 0.910 \\
Total Fe uptake & $<0.001$ & 0.004 & $<0.001$ & 0.005 & 0.031 & 0.263 & 0.024 \\
Total Mn uptake & $<0.001$ & 0.007 & $<0.001$ & $<0.001$ & $<0.001$ & 0.054 & 0.099 \\
Total Zn uptake & $<0.001$ & 0.751 & 0.182 & 0.001 & 0.260 & 0.727 & 0.560 \\
RLD furrow & 0.033 & 0.794 & $<0.001$ & 0.237 & $<0.001$ & 0.270 & 0.429 \\
RLD inter-row & 0.701 & 0.081 & 0.010 & 0.082 & 0.433 & 0.003 & 0.381 \\
Soil water content furrow & $<0.001$ & 0.003 & 0.016 & 0.096 & 0.044 & 0.084 & 0.079 \\
Soil water content inter-row * & $<0.001$ & 0.024 & 0.014 & 0.025 & 0.015 & 0.172 & 0.041 \\
* Log transformation applied & & & & & &
\end{tabular}

Fig. 1 Mean wheat shoot dry matter (g/plant; 51 DAS) in wettable and repellent treatments with variable topsoil thickness (20 or $100 \mathrm{~mm}$ ). Significant differences are greater than the standard error of the difference (SED) multiplied by 2

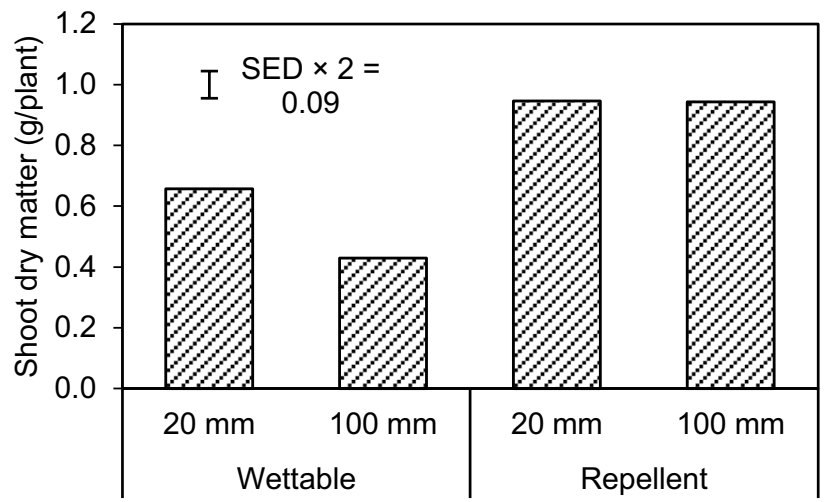


matter significantly decreased in wettable treatments with a $100 \mathrm{~mm}$ topsoil thickness by $35 \%$ compared to $20 \mathrm{~mm}$ topsoil thickness (Fig. 1).

The shoot dry matter was significantly greater when fertiliser was banded below the seed than away from the seed by $23 \%$ (Table 2; Fig. 2). Average shoot dry matter was strongly positively correlated with average tiller number per plant (46 DAS) in both wettable and repellent treatments $(\mathrm{r}=0.89$, respectively; $P<0.01$; data not shown). At this time, no tillers were observed in wettable treatments with a $100 \mathrm{~mm}$ topsoil thickness compared to 2 tillers in the repellent treatments with fertiliser banded below the seed.

\section{Soil water}

The interaction between repellence and fertiliser placement was significant $(P<0.05)$ for soil water content at 51 DAS in the furrow and inter-row (Table 2). Soil water content in the furrow and interrow was significantly greater in wettable treatments (24.9-26.0\% and $22.8-23.7 \%$, respectively) than in repellent treatments $(13.7-19.5 \%$ and $11.1-15.9 \%$, respectively; Table 3), regardless of fertiliser placement. Although there was no effect of fertiliser placement on soil water content in wettable treatments, soil water content in the furrow and inter-row of repellent treatments was significantly greater when fertiliser was banded away from the seed (19.5 and 15.9\%, respectively) than below the seed (13.7 and $11.1 \%$, respectively; Table 3 ).

The interaction between repellence and topsoil thickness was also significant $(P<0.05)$ for soil water content in the inter-row (Table 2), in that soil water content in the inter-row was significantly greater in repellent treatments with a $20 \mathrm{~mm}$ topsoil thickness
(15.8\%) than a $100 \mathrm{~mm}$ topsoil thickness (11.2\%), but no difference was observed in wettable treatments.

The main effect of topsoil thickness was significant $(P<0.05)$ for soil water content in the furrow (Table 2), whereby soil water content in the furrow was significantly greater in treatments with a $100 \mathrm{~mm}$ topsoil thickness $(22.4 \%)$ than a $20 \mathrm{~mm}$ topsoil thickness (19.7\%).

\section{Shoot $\mathrm{N}$ concentration}

At 51 DAS, wheat whole shoots (Fig. 3) in all treatments were below critical levels for $\mathrm{N}$ for that growth stage (i.e., <6.7\%; Reuter and Robinson 1997) but adequate in other key nutrients (data not shown). There were no significant interaction effects on shoot $\mathrm{N}$ concentrations (Table 2), but the main effect of repellence was highly significant for shoot $\mathrm{N}$ concentration $(P<0.001)$, increasing from $5.43 \%$ in wettable treatments to $5.73 \%$ in repellent treatments (Fig. 3).

\section{Wheat total nutrient uptake}

Coinciding with the response in shoot dry matter, there was a significant interaction between

Table 3 Effect of soil water repellence and fertiliser placement on volumetric soil water content (\%) at harvest (51 DAS). Significant differences are greater than the standard error of the difference (SED) multiplied by 2

\begin{tabular}{lllllll}
\hline \multirow{2}{*}{ Soil water content } & \multicolumn{2}{l}{ Wettable } & & \multicolumn{2}{l}{ Repellent } & \multirow{2}{*}{ SED } \\
\cline { 2 - 3 } & Below & Away & & Below & Away & \\
\hline Furrow & 24.9 & 26.0 & & 13.7 & 19.5 & 1.4 \\
Inter-row & 22.8 & 23.7 & & 11.1 & 15.9 & 2.2 \\
\hline
\end{tabular}

Fig. 2 Mean wheat shoot dry matter (g/plant; 51 DAS) in treatments with fertiliser placement either below or away from the seed. Significant differences are greater than the standard error of the difference (SED) multiplied by 2

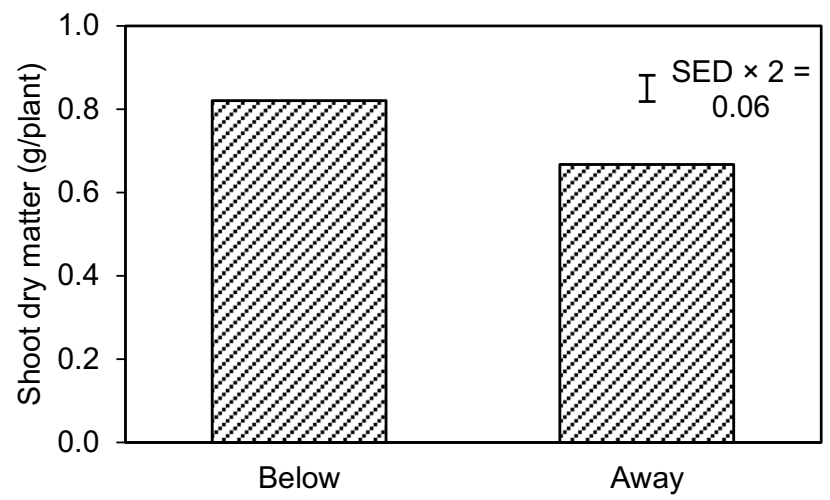


Fig. 3 Mean shoot nitrogen

(N) concentration (51

DAS) in wheat in wettable

and repellent treatments.

Significant differences are

greater than the standard

error of the difference

(SED) multiplied by 2

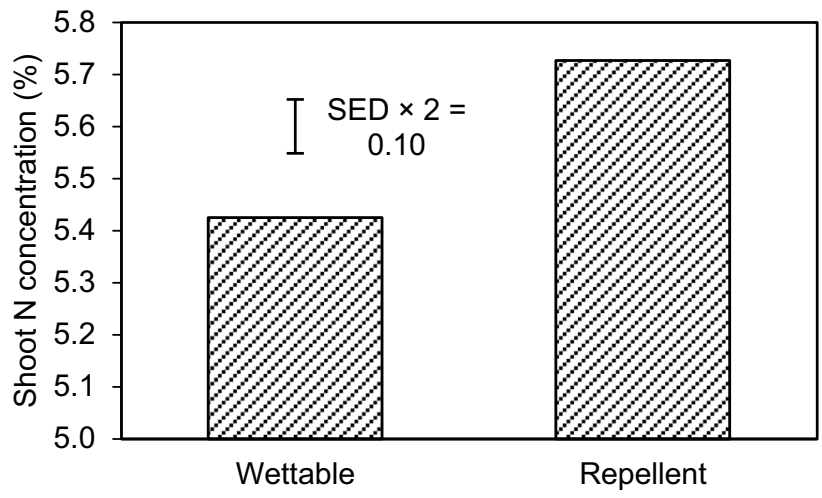

Table 5 Wheat shoot total nutrient uptake (51 DAS) in wettable and repellent treatments with variable fertiliser placement (below or away from the seed). Significant differences are greater than the standard error of the difference (SED) multiplied by 2

\begin{tabular}{|c|c|c|c|c|c|}
\hline \multirow{2}{*}{$\begin{array}{l}\text { Total nutrient } \\
\text { uptake }\end{array}$} & \multicolumn{2}{|c|}{ Wettable } & \multicolumn{2}{|c|}{ Repellent } & \multirow{2}{*}{ SED } \\
\hline & $20 \mathrm{~mm}$ & $100 \mathrm{~mm}$ & $20 \mathrm{~mm}$ & $100 \mathrm{~mm}$ & \\
\hline $\mathrm{N}$ (mg/plant) & 35.9 & 23.3 & 54.3 & 54.3 & 2.6 \\
\hline $\mathrm{K}$ (mg/plant) & 40.8 & 26.4 & 62.0 & 69.5 & 3.0 \\
\hline $\mathrm{Ca}$ (mg/plant) & 3.36 & 2.35 & 4.10 & 4.34 & 0.23 \\
\hline $\operatorname{Mg}$ (mg/plant) & 1.64 & 1.11 & 2.39 & 2.33 & 0.12 \\
\hline $\mathrm{Cu}(\mu \mathrm{g} /$ plant $)$ & 5.44 & 3.11 & 7.30 & 6.24 & 0.36 \\
\hline $\mathrm{Fe}(\mu \mathrm{g} /$ plant $)$ & 47.9 & 31.1 & 69.3 & 71.8 & 3.8 \\
\hline Mn ( $\mu \mathrm{g} /$ plant $)$ & 60.4 & 46.4 & 96.4 & 140.9 & 5.1 \\
\hline $\mathrm{Zn}(\mu \mathrm{g} /$ plant $)$ & 19.5 & 15.7 & 28.4 & 33.8 & 1.6 \\
\hline
\end{tabular}

repellence and topsoil thickness for total uptake of $\mathrm{N}, \mathrm{K}, \mathrm{Ca}, \mathrm{Mg}, \mathrm{Cu}, \mathrm{Fe}, \mathrm{Mn}$, and $\mathrm{Zn}$ (Table 2). Total uptake of $\mathrm{N}, \mathrm{K}, \mathrm{Ca}, \mathrm{Mg}, \mathrm{Cu}, \mathrm{Fe}, \mathrm{Mn}$, and $\mathrm{Zn}$ was significantly greater in repellent treatments than in wettable treatments by an average of $87 \%$ (Table 4), averaged for topsoil thickness. Total uptake of $\mathrm{N}$, $\mathrm{K}, \mathrm{Ca}, \mathrm{Mg}, \mathrm{Cu}, \mathrm{Fe}, \mathrm{Mn}$, and $\mathrm{Zn}$ also significantly decreased in wettable treatments with a $100 \mathrm{~mm}$ topsoil thickness relative to a $20 \mathrm{~mm}$ topsoil thickness by an average of $32 \%$ (Table 4), while total $\mathrm{Cu}$ uptake also significantly decreased in repellent treatments with a $100 \mathrm{~mm}$ topsoil thickness relative to a $20 \mathrm{~mm}$ topsoil thickness by $15 \%$. However, the effect of topsoil thickness on total $\mathrm{N}, \mathrm{Ca}, \mathrm{Mg}$, and $\mathrm{Fe}$ was not observed in repellent treatments. By contrast, total uptake of $\mathrm{K}, \mathrm{Mn}$ and $\mathrm{Zn}$ was significantly greater in repellent treatments with a $100 \mathrm{~mm}$ topsoil thickness than a $20 \mathrm{~mm}$ topsoil thickness by 12,46 , and $19 \%$, respectively (Table 4).

\begin{tabular}{lcccccc}
\hline Total nutrient uptake & \multicolumn{2}{l}{ Wettable } & & \multicolumn{2}{l}{ Repellent } & SED \\
\cline { 2 - 3 } & Below & Away & & Below & Away & \\
\hline $\mathrm{N}$ (mg/plant) & 31.1 & 28.0 & & 61.2 & 47.4 & 2.6 \\
$\mathrm{P}(\mathrm{mg} /$ plant $)$ & 4.65 & 3.43 & & 8.53 & 5.23 & 0.42 \\
$\mathrm{~K}(\mathrm{mg} /$ plant $)$ & 36.8 & 30.4 & & 77.6 & 54.0 & 3.0 \\
$\mathrm{Ca}(\mathrm{mg} /$ plant $)$ & 2.86 & 2.86 & & 4.77 & 3.67 & 0.23 \\
$\mathrm{Mg}(\mathrm{mg} /$ plant $)$ & 1.35 & 1.39 & & 2.59 & 2.13 & 0.12 \\
$\mathrm{Fe}(\mu \mathrm{g} /$ plant $)$ & 43.1 & 35.9 & & 81.0 & 60.1 & 3.8 \\
$\mathrm{Mn}(\mu \mathrm{g} /$ plant $)$ & 56.8 & 50.0 & & 139.6 & 97.7 & 5.1 \\
\hline
\end{tabular}

The interaction between repellence and fertiliser placement was also significant for total uptake of $\mathrm{N}$, $\mathrm{P}, \mathrm{K}, \mathrm{Ca}, \mathrm{Mg}, \mathrm{Fe}$, and $\mathrm{Mn}$ (Table 2). In repellent treatments, total uptake of $\mathrm{N}, \mathrm{P}, \mathrm{K}, \mathrm{Ca}, \mathrm{Mg}, \mathrm{Fe}$, and $\mathrm{Mn}$ was significantly greater when fertiliser was banded below the seed than away from the seed by an average of $38 \%$ (Table 5). However, in wettable treatments, the effect of fertiliser placement was not observed, except for total uptake of $\mathrm{P}$ and $\mathrm{K}$ which also significantly increased when fertiliser was banded below the seed than away from the seed by 36 and $21 \%$, respectively (Table 5).

Wheat root length density

Results showed highly significant $(P<0.001)$ interaction between repellence and fertiliser placement on wheat RLD in the furrow (Table 2). Wheat RLD in the furrow was significantly greater in repellent 
treatments $\left(3.00 \mathrm{~cm} / \mathrm{cm}^{3}\right)$ than in wettable treatments $\left(1.52 \mathrm{~cm} / \mathrm{cm}^{3}\right)$ when fertiliser was banded below the seed (Fig. 4a). However, when fertiliser was banded away from the seed, wheat RLD in the furrow was significantly greater in wettable treatments $(3.84 \mathrm{~cm} /$ $\left.\mathrm{cm}^{3}\right)$ than in repellent treatments $\left(3.12 \mathrm{~cm} / \mathrm{cm}^{3}\right.$; Fig. 4a). In wettable treatments, wheat RLD in the furrow was significantly greater when fertiliser was banded away from the seed $\left(3.84 \mathrm{~cm} / \mathrm{cm}^{3}\right)$ than below the seed $\left(1.52 \mathrm{~cm} / \mathrm{cm}^{3}\right.$; Fig. $\left.4 \mathrm{a}\right)$, but there was no effect of fertiliser placement in repellent treatments.

For wheat RLD in the inter-row, the interaction between topsoil thickness and fertiliser placement was significant $(P<0.005$; Table 2$)$. In treatments with a $100 \mathrm{~mm}$ topsoil thickness, wheat RLD in the inter-row was significantly greater when fertiliser was banded below the seed $\left(1.86 \mathrm{~cm} / \mathrm{cm}^{3}\right)$ than away from the seed $\left(0.43 \mathrm{~cm} / \mathrm{cm}^{3} ;\right.$ Fig. $\left.4 b\right)$. However, there was no effect of fertiliser placement on wheat RLD in the inter-row in treatments with a $20 \mathrm{~mm}$ topsoil thickness. When fertiliser was banded below the seed, wheat RLD in the inter-row was significantly greater in treatments with a $100 \mathrm{~mm}$ topsoil thickness $\left(1.86 \mathrm{~cm} / \mathrm{cm}^{3}\right)$ than a $20 \mathrm{~mm}$ topsoil thickness $\left(0.66 \mathrm{~cm} / \mathrm{cm}^{3}\right.$; Fig. $\left.4 \mathrm{~b}\right)$, despite no effect of topsoil thickness when fertiliser was banded away from the seed.

\section{Correlation analysis}

Despite $\mathrm{N}$ deficiency in wheat plants during early tillering (51 DAS), there was no correlation between shoot $\mathrm{N}$ concentration and shoot dry matter in either wettable or repellent treatments (Table 6). Shoot $\mathrm{P}$ concentration was, however, very strongly positively correlated with tiller number $(r=0.90)$ and dry matter in wettable treatments $(r=0.83$; Table 6$)$, and strongly positively correlated with tiller number in repellent treatments $(r=0.71$; Table 6$)$. Likewise, in wettable treatments, shoot $\mathrm{K}$ concentration was strongly positively correlated with tiller number $(\mathrm{r}=0.79)$ but moderately correlated with dry matter $(r=0.58$; Table 6$)$, with shoot $S$ concentration also strongly positively correlated with tiller number $(r=0.70$; Table 6$)$. However, neither shoot $\mathrm{K}$ nor
Fig. 4 Mean root length density (RLD, $\mathrm{cm} / \mathrm{cm}^{3}$; 51 DAS) of wheat in: (a) wettable and repellent treatments with variable fertiliser placement (below or away from the seed), and (b) in treatments with variable topsoil thickness (20 or $100 \mathrm{~mm}$ ) and variable fertiliser placement (below or away from the seed). Significant differences are greater than the standard error of the difference (SED) multiplied by 2
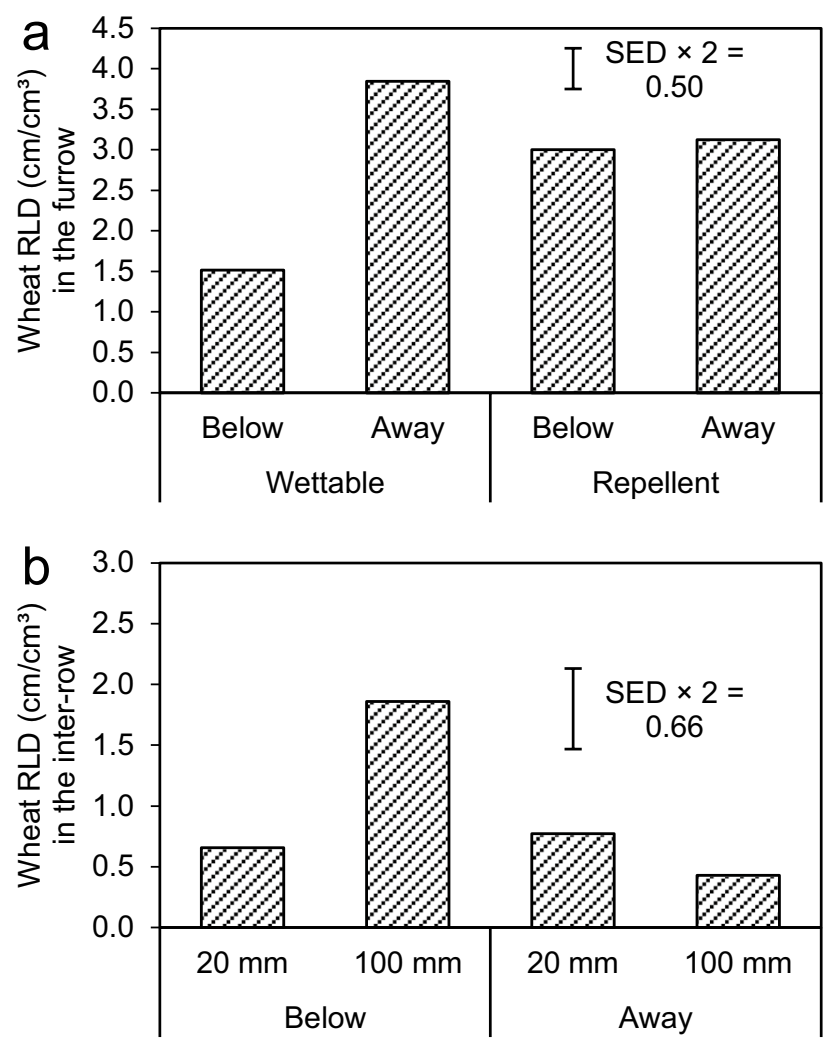
Table 6 Correlation analysis (Pearson's $r$ coefficient) between wheat shoot growth and nutrient parameters at 51 DAS in wettable and repellent treatments. Significance level (two-tailed): $P \leq 0.05\left(^{*}\right), P \leq 0.01(* *)$, and $P \leq 0.001$ (***). Lack of asterisk indicates no significance

\begin{tabular}{|c|c|c|c|c|}
\hline \multirow{2}{*}{$\begin{array}{l}\text { Shoot } \\
\text { nutrient } \\
\text { concentra- } \\
\text { tion }\end{array}$} & \multicolumn{2}{|l|}{ Wettable } & \multicolumn{2}{|l|}{ Repellent } \\
\hline & $\begin{array}{l}\text { Tiller } \\
\text { number } \\
\text { per plant }\end{array}$ & Dry matter & $\begin{array}{l}\text { Tiller } \\
\text { number } \\
\text { per plant }\end{array}$ & Dry matter \\
\hline $\mathrm{N}$ & 0.09 & 0.24 & 0.14 & 0.14 \\
\hline $\mathrm{P}$ & $0.90 * * *$ & $0.83 * * *$ & $0.71 * *$ & 0.52 \\
\hline $\mathrm{K}$ & $0.79 * *$ & $0.58 *$ & 0.26 & 0.37 \\
\hline $\mathrm{S}$ & $0.70^{*}$ & 0.47 & 0.11 & -0.12 \\
\hline
\end{tabular}

S concentration was correlated with shoot growth parameters in repellent treatments.

In general, early wheat growth was strongly negatively correlated to soil water content in the surface layer. In both wettable and repellent treatments, tiller number $(r=-0.87$ and -0.81 , respectively) and shoot dry matter $(r=-0.96$ and -0.91 , respectively; Table 7$)$ were very strongly negatively correlated with soil water content in the furrow at the $0-5 \mathrm{~cm}$ depth. Likewise, in both wettable and repellent treatments,

Table 7 Correlation analysis (Pearson's $r$ coefficient) between soil water content and wheat shoot growth and nutrition parameters in wettable and repellent treatments at 51 DAS. tiller number $(\mathrm{r}=-0.77$ and -0.70 , respectively $)$ and dry matter $(\mathrm{r}=-0.78$ and -0.88 , respectively; Table 7) were also strongly negatively correlated with soil water content in the inter-row at the $0-5 \mathrm{~cm}$ depth. However, there was no significant correlation $(P>0.05)$ between soil water content at the $10-15 \mathrm{~cm}$ depth and shoot growth in either wettable or repellent treatments.

In wettable treatments, total uptake of all nutrients was strongly to very strongly negatively correlated with soil water content at the $0-5 \mathrm{~cm}$ depth in the furrow $(-0.77 \leq \mathrm{r} \leq-0.96$; Table 7$)$ and inter-row $(-0.67 \leq \mathrm{r} \leq-0.92)$. However, there was no correlation between total nutrient uptake and soil water content at $10-15 \mathrm{~cm}$ in wettable treatments. In repellent treatments, total uptake of all nutrients (except for $\mathrm{Mn}$ and $\mathrm{Zn}$ ) was strongly to very strongly negatively correlated $(-0.76 \leq \mathrm{r} \leq-0.97$; Table 7$)$ with soil water content in the furrow at the $0-5 \mathrm{~cm}$ depth. Moreover, in repellent treatments, total uptake of all nutrients (except for $\mathrm{P}$ ) was also strongly to very strongly negatively correlated $(-0.61 \leq \mathrm{r} \leq-0.91$; Table 7$)$ with soil water content in the inter-row at the $0-5 \mathrm{~cm}$ depth. Total uptake of $\mathrm{Mn}$ and $\mathrm{Zn}$ was also strongly negatively correlated with soil water content in the

Significance level (two-tailed): $P \leq 0.05$ (*) $^{*} P \leq 0.01$ (**), and $P \leq 0.001$ (***). Lack of asterisk indicates no significance

\begin{tabular}{|c|c|c|c|c|c|c|c|c|}
\hline \multirow[t]{4}{*}{ Parameter } & \multicolumn{8}{|c|}{ Soil water content } \\
\hline & \multicolumn{4}{|l|}{ Wettable } & \multicolumn{4}{|l|}{ Repellent } \\
\hline & \multicolumn{2}{|l|}{ Furrow } & \multicolumn{2}{|l|}{ Inter-row } & \multicolumn{2}{|l|}{ Furrow } & \multicolumn{2}{|l|}{ Inter-row } \\
\hline & $0-5 \mathrm{~cm}$ & $10-15 \mathrm{~cm}$ & $0-5 \mathrm{~cm}$ & $10-15 \mathrm{~cm}$ & $0-5 \mathrm{~cm}$ & $10-15 \mathrm{~cm}$ & $0-5 \mathrm{~cm}$ & $10-15 \mathrm{~cm}$ \\
\hline Tiller number per plant & $-0.87 * * *$ & $0.58 *$ & $-0.77 * *$ & 0.50 & $-0.81 * *$ & -0.26 & $-0.70^{*}$ & -0.18 \\
\hline Shoot dry matter & $-0.96 * * *$ & 0.38 & $-0.78 * *$ & 0.46 & $-0.91 * * *$ & -0.33 & $-0.88 * * *$ & -0.34 \\
\hline Total N uptake & $-0.96 * * *$ & 0.34 & $-0.78 * *$ & 0.44 & $-0.92 * * *$ & -0.33 & $-0.89 * * *$ & -0.35 \\
\hline Total P uptake & $-0.94 * * *$ & 0.46 & $-0.76 * *$ & 0.48 & $-0.80 * *$ & 0.18 & -0.56 & 0.19 \\
\hline Total K uptake & $-0.95 * * *$ & 0.38 & $-0.81 * *$ & 0.42 & $-0.76^{* *}$ & -0.43 & $-0.90 * * *$ & -0.53 \\
\hline Total Ca uptake & $-0.91 * * *$ & 0.24 & $-0.77 * *$ & 0.39 & $-0.85 * * *$ & -0.44 & $-0.83 * * *$ & -0.49 \\
\hline Total Mg uptake & $-0.90 * * *$ & 0.19 & $-0.71 * *$ & 0.38 & $-0.97 * * *$ & -0.34 & $-0.84 * * *$ & -0.32 \\
\hline Total S uptake & $-0.90 * * *$ & 0.37 & $-0.82 * *$ & 0.34 & $-0.84 * * *$ & 0.09 & $-0.62 *$ & 0.15 \\
\hline Total B uptake & $-0.77 * *$ & 0.29 & $-0.92 * * *$ & 0.22 & $-0.82 * *$ & 0.10 & $-0.64^{*}$ & 0.12 \\
\hline Total Cu uptake & $-0.92 * * *$ & 0.34 & $-0.67 *$ & 0.51 & $-0.80^{* *}$ & 0.04 & $-0.61^{*}$ & 0.12 \\
\hline Total Fe uptake & $-0.93 * * *$ & 0.34 & $-0.80 * *$ & 0.38 & $-0.85 * * *$ & -0.41 & $-0.91 * * *$ & -0.44 \\
\hline Total Mn uptake & $-0.89 * * *$ & 0.23 & $-0.87 * * *$ & 0.26 & -0.41 & $-0.59 *$ & $-0.82 * * *$ & $-0.78 * *$ \\
\hline Total Zn uptake & $-0.82 * * *$ & 0.05 & $-0.82 * *$ & 0.17 & -0.50 & $-0.75 * *$ & $-0.81 * *$ & $-0.79 * *$ \\
\hline
\end{tabular}


furrow ( $\mathrm{r}=-0.59$ and -0.75 , respectively) and interrow $(r=-0.78$ and -0.79 , respectively; Table 7$)$ at the $10-15 \mathrm{~cm}$ depth in repellent treatments.

\section{Discussion}

Benefits of plant growth and nutrition

Adverse effects of soil water repellence on crop emergence, growth, and yield are generally attributed to uneven soil wetting, reduced soil water storage, and the prevalence of dry soil patches (Doerr et al. 2000; Kramers et al. 2005; Li et al. 2019; Roper et al. 2015). The same processes are likely to affect the availability of nutrients from soil and fertiliser (Blackwell 1993). However, contrary to the hypothesis that nutrient uptake and plant growth would be impeded by repellence, this study demonstrated that severe repellence in a sandy loam soil significantly increased wheat tiller number (by up to 2 tillers; 46 DAS), shoot dry matter (by 82\%; 51 DAS), and total nutrient uptake (by 87\%; 51 DAS) per plant relative to completely wettable soil, under regular but low water supply (4.2 mm every two days; average day air temperature of $19{ }^{\circ} \mathrm{C}$ and relative humidity of $36 \%$ ). Water infiltration did not cause drainage from treatment containers even in the wettable furrow of repellent treatments, which was presumed to have experienced preferential flow. However, water infiltration in the wettable furrow of repellent treatments was found to nearly double wheat RLD in the furrow (from 1.52 to $3.00 \mathrm{~cm} / \mathrm{cm}^{3}$ ) relative to wettable treatments when fertiliser was banded below the seed, suggesting that water and nutrient transport in repellent treatments with a wettable furrow were conducive to early root growth and nutrient uptake under regular but low water supply. Although wheat plants in all treatments were relatively deficient in N (i.e., $<6.7 \%$; Reuter and Robinson 1997), shoot $\mathrm{N}$ concentrations (51 DAS) were also significantly greater in repellent treatments (5.73\%) than in wettable treatments $(5.43 \%)$.

Our results support the argument put forward by Ruthrof et al. (2019) that there is scope to re-frame research on repellence from a problem to overcome, to an opportunity to be managed. In wettable topsoil treatments, applied water and nutrients were less efficiently utilised by plants, possibly due to a greater retention of water close to the surface and a reduction in soil wetting depth. Given that $100 \%$ of the topsoil volume was wettable in wettable treatments compared to less than $10 \%$ (i.e., wettable furrow) in repellent treatments at the start of the experiment, water applied would be distributed over a greater wettable surface area but at a limited depth in wettable treatments relative to deeper wetting below the wettable furrow in repellent treatments. Water retained in the upper soil layer of the wettable topsoil is consequently more prone to evaporative water loss from the soil surface, decreasing the overall plant-available water supply (Bachmann et al. 2001; Rye and Smettem 2017). Moreover, as soils wet up from an air-dry state, the proportion of water held in the range between the air-dry and permanent wilting point (i.e., water that is not plant-available; Armstrong et al. 2001) would also be greater in wettable treatments due to a greater volume of wettable air-dry soil. This will further reduce the actual volume of water that is plant-available (i.e., between permanent wilting point and field capacity) and will be particularly important under conditions where rainfall occurs in small increments. Thus, under such conditions repellence may be an advantage, if the water can enter the deeper soil.

Under a limited water supply, increased evaporative water loss and decreased soil wetting depth may lead to the development of shallow root systems where the soil is more prone to rapid drying (Dunbabin et al. 2003; Weaver 1926). This may explain why early shoot dry matter production and total nutrient uptake (particularly $\mathrm{N}$ nutrition) in wheat were significantly limited in wettable treatments relative to repellent treatments. The thicker wettable topsoil would exacerbate such problems, which were also clearly demonstrated by further reductions in early shoot dry matter (by 35\%) and total uptake of N, K, $\mathrm{Ca}, \mathrm{Mg}, \mathrm{Cu}, \mathrm{Fe}, \mathrm{Mn}$, and $\mathrm{Zn}$ (by an average of $32 \%$ ) in wettable treatments with a $100 \mathrm{~mm}$ topsoil thickness relative to a $20 \mathrm{~mm}$ topsoil thickness. The results did not suggest any influence of either root disease in wettable treatments or phytotoxicity due to wetting agent application, given that (a) wheat RLD in the furrow was significantly greater in wettable treatments than in repellent treatments when fertiliser was banded away from the seed, and (b) wheat RLD in the inter-row was generally greater in treatments with a thicker topsoil.

In water-repellent soils with managed infiltration in wettable furrows, there is an opportunity to divert 
water to the subsoil via preferential flow pathways (Ritsema and Dekker 1994) while lessening the evaporation of water due to an increase in the diffusion resistance of the soil which reduces the upward capillary movement of water (DeBano 1981; Imeson et al. 1992). As a result, these changes in soil wetting patterns could sequester a significant fraction of water at depth via increased thermal insulation and increased path lengths to the surface (Smettem et al. 2021), which could benefit plants as a water harvesting mechanism (Cammeraat and Imeson 1999). Gupta et al. (2015) found that wettable soils with a $20 \mathrm{~mm}$ repellent topsoil layer were able to retain up to $90 \%$ of water after $83 \mathrm{~h}$ by significantly decreasing evaporation rates relative to a complete loss of water from completely wettable soils (control). In another experiment, they also showed a significant increase in the shoot and root growth of young chickpea (Cicer arietinum) plants in wettable soils treated with a $20 \mathrm{~mm}$ thick repellent topsoil relative to the control, but no nutrient uptake results were presented. In the present study, soil water at harvest (51 DAS) in wettable treatments was nearly double that in repellent treatments, which appears to contradict our conclusions that a wettable base to the furrow on a water-repellent soil will funnel water more effectively into the root zone. Based on work by Lowe et al. (2017) where soil water was continuously monitored via electrical resistivity tomography, water infiltration in very severely repellent soils (MED 4.2 M) was concentrated in the furrow where surfactant was applied, increasing the volumetric water content by up to $40 \%$ below the furrow at the $20 \mathrm{~mm}$ depth. Increased water infiltration below the furrow would thus be consistent with the observed increases in early wheat shoot growth and nutrient uptake. Hence, we attribute the present result to the higher leaf area of wheat at 51 DAS in the water-repellent treatments which would dry out soil water faster than from the completely wettable treatments.

Benefits for root foraging and nutrient uptake

Despite prolonged dryness of topsoil in the interrow of repellent treatments, shoot and root growth and nutrient uptake of young wheat plants were not impeded, presumably due to an adequate water and nutrient supply in the root zone as a result of preferential flow in the wettable furrow. Compared to the bulk volume of soil, these preferential flow paths are potentially enriched zones of water, nutrients, and organic substrate (Bundt et al. 2001; Guggenberger and Kaiser 2003; Morales et al. 2010) and would, therefore, provide 'hotspots' for root foraging and nutrient acquisition in water-repellent soils, especially when nutrients are placed in rows below or adjacent to seeds. Under a heterogeneous nutrient supply, preferential root placement, root proliferation, and increased uptake kinetics in localised resourceenriched zones can result in increased plant nutrient use efficiency, early biomass, and nutrient accumulation in shoots (Day et al. 2003a; Ma et al. 2011; Rose et al. 2009), even if uptake is suppressed in deficient zones (Robinson 1994). Such positive responses to soil nutrient heterogeneity have been reported in various crops such as wheat (Ma and Rengel 2008; Ma et al. 2007; Trapeznikov et al. 2003), barley (Drew 1975; Drew and Saker 1978), maize (Li et al. 2012; Yu et al. 2014), canola (Rose et al. 2009), and lupin (Ma et al. 2011), and in perennial grasses (Day et al. 2003b). In this present study, the observed improvement in early vigour of wheat plants in repellent treatments with a wettable furrow relative to completely wettable treatments could, therefore, be attributed to an increase in water and nutrient availability in the furrow due to preferential flow which favoured root foraging and plant uptake. By contrast, the observed increase in wheat RLD in the furrow of wettable treatments relative to repellent treatments, when fertiliser was banded away from the seed, could likely be explained by a greater carbon allocation to roots at the expense of shoots to increase water and nutrient absorption capacity in response to drought and/ or nutrient stress (Gregory et al. 1995; Khan et al. 2010). Nevertheless, later in the wheat growth cycle the persistence of dry zones in repellent treatments could become a limitation to plant nutrient use efficiency if mineralisation of organically-bound nutrients is restricted and roots are unable to forage therein (Cisar et al. 2000; Roper et al. 2015). Alternatively, delayed wetting and mineralisation of these dry zones may result in nutrients being released at a later stage in crop phenological development when nutrient demand is higher and root systems are more developed (Roper et al. 2015).

In drying soils, the hydraulic conductivity decreases dramatically, decreasing soil water redistribution and plant water uptake (Lobet et al. 2014), 
and the flux of nutrients to the root (Hoad et al. 2001). Since small root systems during early plant establishment are likely to be constrained by limited soil-root contact, improvements in early shoot and root development and rooting depth could be important for increasing root exploitation of the soil matrix, increase water and nutrient uptake, and improve plant growth and nutrition (Andresen et al. 2016), which can lead to higher yields (Fageria and Moreira 2011). Such mechanisms are particularly critical in arid and semi-arid dryland cropping systems as they confer on plants the advantage of extracting water from subsurface soil layers that could otherwise be lost by evaporation and/or increase access to subsurface water and nutrient supplies (Fageria and Moreira 2011; Shao et al. 2008). In this study, given that early plant growth and nutrient uptake were strongly related to soil water content in the upper $0-5 \mathrm{~cm}$ depth, the greater protection of plant-available water in the upper soil layer from evaporation due to repellence could have played an important role in early wheat growth and nutrition in repellent treatments relative to wettable treatments under regular but low water supply.

In the early developmental stages of growth, enhanced plant vigour is desirable for the uptake of key macronutrients, such as N (Pang et al. 2014; Sarkar and Baishya 2017), P (Fageria and Moreira 2011; Grant et al. 2001), K (Kant et al. 2005; Mallarino et al. 1999), and S (Naeem and MacRitchie 2003; Zhao et al. 1997), which influence crop yield, quality, and resistance to pests and environmental stress (Dordas 2008; Kumar and Sharma 2013). In this study, although wheat plants in all treatments were relatively deficient in $\mathrm{N}$, correlation analysis suggests that overall $\mathrm{P}$ nutrition and, to a lesser extent, $\mathrm{K}$ and $\mathrm{S}$ nutrition may have been limiting early wheat shoot dry matter production in wettable treatments. By contrast, the lack of correlation between shoot dry matter and shoot nutrient concentrations in repellent treatments could indicate that, nutrient uptake did not impede shoot growth, presumably due to increased soil water availability in the root zone and improved access to banded fertiliser.

Regardless of repellence and topsoil thickness, nutrient placement closer to the root zone can stimulate early growth and plant vigour by increasing accessibility of nutrients to plant roots early in the growing season (Mahler 1985). This is particularly important for immobile nutrients such as $\mathrm{P}$ which tend to stratify within fertilised topsoil (Ma et al. 2009) and cannot be sufficiently transported by mass flow or diffusion (Jones and Jacobsen 2009; Marschner 2002). In this study, banding fertiliser below the seed significantly increased wheat shoot dry matter (by 23\%) and the total uptake of N, P, K, Ca, S, B, $\mathrm{Cu}, \mathrm{Fe}$, and $\mathrm{Mn}$ per plant (by $34 \%$ on average) relative to inter-row placement.

\section{Seeding and water harvesting technologies}

Preferential water flow in the wettable furrow base of severely repellent topsoil treatments favoured early wheat growth and nutrient uptake, despite prolonged soil dryness and a possible reduction in root volume in repellent inter-rows. Field studies involving furrow sowing and banded wetting agents in water-repellent soils have been reported to promote more uniform and deeper wetting depths along the furrow that significantly increased germination and yield of various crops (wheat, barley, and lupin; Crabtree and Gilkes 1999a; Crabtree and Henderson 1999) and pastures (subterranean clover, dryland lucerne, tagasaste, phalaris, and perennial ryegrass; Crabtree and Gilkes 1999b) when used in combination with press-wheels for improved furrow definition and seed-soil contact. However, the previous studies did not examine the effects on plant nutrient uptake, which were shown in the present study to be a significant factor in the plant response. While water harvesting can be achieved by furrow sowing (Blackwell 1993), benefits could be negated or problems exacerbated if dry, water-repellent soil flows behind the seeding tyne and covers the seed, resulting in poor wetting of the seed zone and hence germination (Davies et al. 2012). Seeding systems with winged knife-points have thus been proposed to better manage repellence by grading waterrepellent soil away from the furrow to the ridges and to prevent backfilling (Davies et al. 2012; Roper et al. 2015; Unkovich et al. 2015). By contrast, recent field studies by Hall et al. (2020) found no effect of winged knife-points on the grain yield of wheat, canola, and barley over five successive cropping seasons relative to knife-points on a pale deed sand in Western Australia. However, crop production at this site was confounded by other constraints, such as soil compaction and $\mathrm{K}$ deficiency, as their alleviation via strategic deep tillage (spading and mouldboard ploughing) and 
subsoil clay addition produced the largest crop yield responses. Future research should, therefore, be conducted on different soil types, primarily constrained by repellence, to determine the seeding technologies that best capture the benefits of water harvesting and repellence for crop growth, nutrition, and production.

The potential to enhance rainfall and runoff capture (water harvesting) could, therefore, play an important role in early plant vigour and nutrient uptake on water-repellent soils, particularly in semiarid and Mediterranean dryland cropping systems where seasonal water deficits are common (Blackwell 2000; DeBano 2000; Roper et al. 2015) and/ or where regions are at risk of declining rainfall and increased frequency of dry days (e.g., southwest region of WA; Alexander et al. 2007; Hope 2006; Suppiah and Hennessy 1998). Indeed, for agriculture in the eastern wheatbelt of south-western WA, Scanlon and Doncon (2020) have reported a 24\% increase in dry growing seasons and a 14-20\% (28-50 mm) decrease in growing-season rainfall (i.e., April-October) post-2000. They found that such decreases in growing-season rainfall were predominantly during May-July, coinciding with early crop establishment which could have important implications for crop growth and yield. Efforts to maximise utilization of growing-season rainfall by plants, especially autumn break-of-season rainfall, through rainwater harvesting and decreasing evaporative water loss could thus be important for future dryland crop production in the southwest of WA.

Additional studies are warranted under variable water supply and plant density to better understand the dynamic responses of early wheat growth and nutrition to repellence, with continuous measurement of soil water and nutrient availability. Moreover, treatment effects need to be assessed under higher water supply, especially to define the circumstances where excessive leaching of nutrients could have adverse implications for furrow-sown plant growth (van der Paauw 1962) and to understand how the benefits of repellence could be harnessed.

\section{Conclusions}

Contrary to our hypothesis, severely water-repellent sandy loam topsoil with a wettable furrow base and uniform plant density significantly improved wheat tiller number (46 DAS), shoot dry matter, shoot $\mathrm{N}$ concentration, and total nutrient uptake per plant (51 DAS) relative to completely wettable topsoil treatments, under regular but low water supply, regardless of topsoil thickness (20 or $100 \mathrm{~mm}$ ) and fertiliser band placement (below or away from the seed). Repellent topsoil treatments were also found to nearly double wheat RLD in the furrow relative to wettable treatments when fertiliser was banded below the seed. Such increases in early shoot and root growth and nutrient uptake in repellent treatments were attributed to preferential flow in the wettable furrow which increased soil water availability in the root zone without causing drainage from the base of treatment containers. While topsoil thickness was not important in repellent treatments, wettable treatments with a thicker $(100 \mathrm{~mm})$ topsoil layer significantly reduced wheat growth and nutrient uptake, presumably due to an overall reduction in plant-available water during the early growth period. Results highlight the importance of plant-available water in the root zone for early wheat growth and nutrient uptake in a waterrepellent sand, under a regular but low water supply. Adopting water harvesting techniques such as furrow sowing and banding wetting agents could, therefore, be an effective strategy for managing early crop growth and nutrition on water-repellent soils by maximising the use efficiency of water and nutrients after small rainfall events. Studies should validate the efficacy of water-repellent topsoil for water harvesting and its effects on soil water and nutrient availability at depth and the persistence of effects to grain harvest. How early wheat growth and nutrition may respond to other factors such as water supply, surface topography, and plant density should also be studied given their relevance for semi-arid and Mediterranean dryland crop production on water-repellent soils.

Acknowledgements The authors gratefully acknowledge the financial support of Grains Research and Development Corporation (GRDC) Australia (Project DAW00244 and CUR00026).

Authors' contributions All authors, apart from Katia Stefanova, contributed to the study conception and design. Material preparation, investigation, and data collection were performed by Simon Yeap. Formal analysis was performed by Katia Stefanova. Supervision was provided by Richard Bell, Richard Harper, and Craig Scanlan. Funding from the Grains Research and Development Corporation (Project DAW00244) was acquired by Stephen Davies. The first draft of the manuscript was written by Simon Yeap and all authors commented 
on earlier versions of the manuscript. All authors read and approved the final manuscript.

Funding Open Access funding enabled and organized by CAUL and its Member Institutions. This work was funded by the Grains Research and Development Corporation (GRDC) Australia (Project DAW00244 and CUR00026).

Data availability The datasets generated during and/or analysed during the current study are available from the corresponding author on reasonable request.

Code availability Not applicable.

\section{Declarations}

Conflicts of interest/Competing interests The authors have no relevant financial or non-financial interests to disclose.

Open Access This article is licensed under a Creative Commons Attribution 4.0 International License, which permits use, sharing, adaptation, distribution and reproduction in any medium or format, as long as you give appropriate credit to the original author(s) and the source, provide a link to the Creative Commons licence, and indicate if changes were made. The images or other third party material in this article are included in the article's Creative Commons licence, unless indicated otherwise in a credit line to the material. If material is not included in the article's Creative Commons licence and your intended use is not permitted by statutory regulation or exceeds the permitted use, you will need to obtain permission directly from the copyright holder. To view a copy of this licence, visit http://creativecommons.org/licenses/by/4.0/.

\section{References}

Alazawi S (2015) Hydrophobic sand to combat water scarcity Properties and possible chemical risk. Royal Institute of Technology (KTH), Stockholm, Sweden.

Alexander L, Hope P, Collins D, Trewin B, Lynch A, Nicholls $N$ (2007) Trends in Australia's climate means and extremes: A global context. Aust Meteorol Mag 56:1-18

Andresen M, Dresbøll DB, Jensen LS, Magid J, ThorupKristensen K (2016) Cultivar differences in spatial root distribution during early growth in soil, and its relation to nutrient uptake - a study of wheat, onion and lettuce. Plant Soil 408:255-270. https://doi.org/10.1007/ s11104-016-2932-z

Angus JF (2001) Nitrogen supply and demand in Australian agriculture. Aust J Exp Agric 41:277-288. https://doi. org/10.1071/EA00141

Armstrong D, Cotching WE, Bastick C (2001) Assessing your soil resources for irrigation, Wise Watering Irrigation Management Course notes. https://dpipwe.tas.gov.au/ Documents/2-Soil-Resources-V4.pdf. Accessed $16 \mathrm{Jul}$ 2021
Bachmann J, Horton R, Van der Ploeg RR (2001) Isothermal and nonisothermal evaporation from four sandy soils of different water repellency. Soil Sci Soc Am J 65:15991607. https://doi.org/10.2136/sssaj2001.1599

Bauters TWJ, DiCarlo DA, Steenhuis TS, Parlange JY (1998) Preferential flow in water-repellent sands. Soil Sci Soc Am J 62:1185-1190. https://doi.org/10.2136/sssaj1998. 03615995006200050005x

Bisdom EBA, Dekker LW, Schoute JFT (1993) Water repellency of sieve fractions from sandy soils and relationships with organic material and soil structure. Geoderma 56:105-118. https://doi.org/10.1016/0016-7061(93) 90103-R

Blackwell P (1993) Improving sustainable production from water repellent sands. J Dep Agric West Aust 34:160-167

Blackwell PS (2000) Management of water repellency in Australia, and risks associated with preferential flow, pesticide concentration and leaching. J Hydrol 231232:384-395. https://doi.org/10.1016/S0022-1694(00) 00210-9

Bond RD (1972) Germination and yield of barley when grown in a water-repellent sand. Agron J 64:402-403. https://doi.org/10.2134/agronj1972.000219620064000 30043x

Bundt M, Widmer F, Pesaro M, Zeyer J, Blaser P (2001) Preferential flow paths: biological 'hot spots' in soils. Soil Biol Biochem 33:729-738. https://doi.org/10.1016/ S0038-0717(00)00218-2

Cammeraat LH, Imeson AC (1999) The evolution and significance of soil-vegetation patterns following land abandonment and fire in Spain. CATENA 37:107-127. https://doi.org/10.1016/S0341-8162(98)00072-1

Cisar JL, Williams KE, Vivas HE, Haydu JJ (2000) The occurrence and alleviation by surfactants of soil-water repellency on sand-based turfgrass systems. J Hydrol 231232:352-358. https://doi.org/10.1016/S0022-1694(00) 00207-9

Cornforth IS (1968) Relationships between soil volume used by roots and nutrient accessibility. J Soil Sci 19:291-301. https://doi.org/10.1111/j.1365-2389.1968.tb01541.x

Crabtree WL, Gilkes RJ (1999a) Banded wetting agent and compaction improve barley production on a water-repellent sand. Agron J 91:463-467. https://doi.org/10.2134/ agronj1999.00021962009100030017x

Crabtree WL, Gilkes RJ (1999b) Improved pasture establishment and production on water-repellent soils. Agron J 91:467-470. https://doi.org/10.2134/agronj1999.00021 $962009100030018 x$

Crabtree WL, Henderson CWL (1999) Furrows, press wheels and wetting agents improve crop emergence and yield on water repellent soils. Plant Soil 214:1-8. https://doi.org/ 10.1023/A: 1004314427626

Davies S, Blackwell P, Bakker D, Scanlan C, Roper M, Ward $P$ (2012) Developing and assessing agronomic strategies for water repellent soils. Agribusiness Crop Updates. Department of Agriculture and Food/Grains Research and Development Corporation, Perth

Day KJ, Hutchings MJ, John EA (2003a) The effects of spatial pattern of nutrient supply on the early stages of growth in plant populations. J Ecol 91:305-315. https://doi.org/10. 1046/j.1365-2745.2003.00763.x 
Day KJ, John EA, Hutchings MJ (2003b) The effects of spatially heterogeneous nutrient supply on yield, intensity of competition and root placement patterns in Briza media and Festuca ovina. Funct Ecol 17:454-463. https://doi. org/10.1046/j.1365-2435.2003.00758.x

DeBano LF (1981) Water repellent soils: a state-of-theart. General Technical Report PSW-46. United States Department of Agriculture Forest Service, Pacific Southwest Forest and Range Experiment Station, Berkeley, California

DeBano LF (2000) Water repellency in soils: a historical overview. J Hydrol 231-232:4-32. https://doi.org/10.1016/ S0022-1694(00)00180-3

Dekker LW, Ritsema CJ (1996) Uneven moisture patterns in water repellent soils. Geoderma 70:87-99. https://doi. org/10.1016/0016-7061(95)00075-5

Doerr SH, Shakesby RA, Walsh RPD (2000) Soil water repellency: its causes, characteristics and hydro-geomorphological significance. Earth Sci Reviews 51:33-65. https:// doi.org/10.1016/S0012-8252(00)00011-8

Dordas C (2008) Role of nutrients in controlling plant diseases in sustainable agriculture. A Review Agron Sustain Dev 28:33-46. https://doi.org/10.1051/agro:2007051

Drew MC (1975) Comparison of the effects of a localized supply of phosphate, nitrate, ammonium and potassium on the growth of the seminal root system, and the shoot, in barley. New Phytol 75:479-490. https://doi.org/10. 1111/j.1469-8137.1975.tb01409.x

Drew MC, Saker LR (1978) Nutrient supply and the growth of the seminal root system in barley: III. Compensatory increases in growth of lateral roots, and in rates of phosphate uptake, in response to a localized supply of phosphate. J Exp Bot 29:435-451. https://doi.org/10.1093/ $\mathrm{jxb} / 29.2 .435$

Dunbabin V, Diggle A, Rengel Z (2003) Is there an optimal root architecture for nitrate capture in leaching environments? Plant Cell Environ 26:835-844. https://doi.org/ 10.1046/j.1365-3040.2003.01015.x

Fageria NK, Moreira A (2011) The role of mineral nutrition on root growth of crop plants. In: DL Sparks (ed) Advances in Agronomy. Academic Press, Burlington.

Franco CMM, Clarke PJ, Tate ME, Oades JM (2000) Hydrophobic properties and chemical characterisation of natural water repellent materials in Australian sands. J Hydrol 231-232:47-58. https://doi.org/10.1016/S0022-1694(00) 00182-7

Goebel M-O, Bachmann J, Reichstein M, Janssens IA, Guggenberger G (2011) Soil water repellency and its implications for organic matter decomposition - is there a link to extreme climatic events? Glob Change Biol 17:26402656. https://doi.org/10.1111/j.1365-2486.2011.02414.x

Grant CA, Flaten DN, Tomasiewicz DJ, Sheppard SC (2001) The importance of early season phosphorus nutrition. Can J Plant Sci 81:211-224. https://doi.org/10.4141/ P00-093

Gregory PJ, Palta JA, Batts GR (1995) Root systems and root:mass ratio-carbon allocation under current and projected atmospheric conditions in arable crops. Plant Soil 187:221-228. https://doi.org/10.1007/BF00017089

Guggenberger G, Kaiser K (2003) Dissolved organic matter in soil: challenging the paradigm of sorptive preservation.
Geoderma 113:293-310. https://doi.org/10.1016/S00167061(02)00366-X

Gupta B, Shah DO, Mishra B, Joshi PA, Gandhi VG, Fougat RS (2015) Effect of top soil wettability on water evaporation and plant growth. J Colloid Interface Sci 449:506513. https://doi.org/10.1016/j.jcis.2015.02.018

Hall DJM, Davies SL, Bell RW, Edwards TJ (2020) Soil management systems to overcome multiple constraints for dryland crops on deep sands in a water limited environment on the south coast of Western Australia. Agron 10. https://doi.org/10.3390/agronomy10121881

Harper RJ, Gilkes RJ (1994) Soil attributes related to water repellency and the utility of soil survey for predicting its occurrence. Soil Res 32:1109-1124. https://doi.org/10. 1071/SR9941109

Hendrickx JMH, Dekker LW, Boersma OH (1993) Unstable wetting fronts in water-repellent field soils. J Environ Qual 22:109-118. https://doi.org/10.2134/jeq1993.00472 425002200010014x

Herbert A (2009) Opportunity costs of land degradation hazards in the South-West Agricultural Region: Calculating the costs of production losses due to land degradation. Resource Management Technical Report 349. Department of Agriculture and Food Western Australia, Perth, Western Australia

Hoad S, Russell G, Lucas ME, Bingham I (2001) The management of wheat, barley, and oat root systems. In: Sparks DL (ed) Advances in Agronomy. Academic Press, San Diego

Hope PK (2006) Projected future changes in synoptic systems influencing southwest Western Australia. Clim Dyn 26:765-780. https://doi.org/10.1007/s00382-006-0116-x

Hoyle F (2013) Managing Soil Organic Matter: A Practical Guide. Grains Research and Development Corporation, Canberra

Imeson AC, Verstraten JM, van Mulligen EJ, Sevink J (1992) The effects of fire and water repellency on infiltration and runoff under Mediterranean type forest. CATENA 19:345-361. https://doi.org/10.1016/0341-8162(92) 90008-Y

Isbell R (2016) The Australian Soil Classification. CSIRO Publishing, Victoria

Jones C, Jacobsen J (2009) Fertilizer placement and timing. MSU Extension Publication 4449-11. Montana State University, Bozeman, Montana

Kant S, Kant P, Kafkafi U (2005) Potassium uptake by higher plants: From field application to membrane transport. Acta Agron Hung 53:443-459. https://doi.org/10.1556/ AAgr.53.2005.4.11

Khan A, Ul-Allah S, Sadique S (2010) Genetic variability and correlation among seedling traits of wheat (Triticum aestivum) under water stress. Int J Agric Biol 2:247-250

Kianmeher P, Alazawi S, Gustafsson JP (2016) Applicability of hydrophobic sand to combat water scarcity and possible chemical risk. 75th The IIER International Conference, Zurich, Switzerland

King PM (1981) Comparison of methods for measuring severity of water repellence of sandy soils and assessment of some factors that affect its measurement. Soil Res 19:275-285. https://doi.org/10.1071/SR9810275 
Kirkegaard JA, Lilley JM, Howe GN, Graham JM (2007) Impact of subsoil water use on wheat yield. Australian J Agric Res 58:303-315. https://doi.org/10.1071/AR06285

Kramers G, van Dam JC, Ritsema CJ, Stagnitti F, Oostindie K, Dekker LW (2005) A new modelling approach to simulate preferential flow and transport in water repellent porous media: Parameter sensitivity, and effects on crop growth and solute leaching. Soil Res 43:371-382. https:// doi.org/10.1071/SR04098

Kumar P, Sharma MK (2013) Nutrient Deficiencies of Field Crops: Guide to Diagnosis and Management. CABI, Wallingford

Lehmann J, Schroth G (2003) Nutrient leaching. In: Schroth G, Sinclair FL (eds) Trees, Crops and Soil Fertility: Concepts and Research Methods. CABI Publishing, Wallingford

Li H-B, Zhang F-S, Shen J-B (2012) Contribution of root proliferation in nutrient-rich soil patches to nutrient uptake and growth of maize. Pedosphere 22:776-784. https:// doi.org/10.1016/S1002-0160(12)60063-0

Li Y, Ren X, Hill R, Malone R, Zhao Y (2018) Characteristics of water infiltration in layered water-repellent soils. Pedosphere 28:775-792. https://doi.org/10.1016/S10020160(17)60414-4

Li Y, Yao N, Tang D, Chau HW, Feng H (2019) Soil water repellency decreases summer maize growth. Agric for Meteorol 266-267:1-11. https://doi.org/10.1016/j.agrfo rmet.2018.12.001

Liao M, Palta JA, Fillery IRP (2006) Root characteristics of vigorous wheat improve early nitrogen uptake. Aust J Agric Res 57:1097-1107. https://doi.org/10.1071/AR054 39

Lobet G, Couvreur V, Meunier F, Javaux M, Draye X (2014) Plant water uptake in drying soils. Plant Physiol 164:1619-1627. https://doi.org/10.1104/pp.113.233486

Lowe M-A, McGrath G, Mathes F, Leopold M (2017) Evaluation of surfactant effectiveness on water repellent soils using electrical resistivity tomography. Agric Water Manag 181:56-65. https://doi.org/10.1016/j.agwat.2016. 11.013

Ma Q, Rengel Z (2008) Phosphorus acquisition and wheat growth are influenced by shoot phosphorus status and soil phosphorus distribution in a split-root system. J Plant Nutr Soil Sci 171:266-271. https://doi.org/10.1002/jpln. 200700183

Ma Q, Rengel Z, Bowden B (2007) Heterogeneous distribution of phosphorus and potassium in soil influences wheat growth and nutrient uptake. Plant Soil 291:301-309. https://doi.org/10.1007/s11104-007-9197-5

Ma Q, Rengel Z, Rose T (2009) The effectiveness of deep placement of fertilisers is determined by crop species and edaphic conditions in Mediterranean-type environments: a review. Soil Res 47:19-32. https://doi.org/10.1071/ SR08105

Ma Q, Rengel Z, Siddique KHM (2011) Wheat and white lupin differ in root proliferation and phosphorus use efficiency under heterogeneous soil $\mathrm{P}$ supply. Crop Pasture Sci 62:467-473. https://doi.org/10.1071/CP10386

Mahler RL (1985) Fertilizer placement. Coorperative Extension System CIS 757. Idaho Agricultural Experiment Station, University of Idaho, Moscow
Mainwaring K, Hallin IL, Douglas P, Doerr SH, Morley CP (2013) The role of naturally occurring organic compounds in causing soil water repellency. Eur J Soil Sci 64:667-680. https://doi.org/10.1111/ejss.12078

Mallarino AP, Bordoli JM, Borges R (1999) Phosphorus and potassium placement effects on early growth and nutrient uptake of no-till corn and relationships with grain yield. Agron J 91:37-45. https://doi.org/10.2134/agronj1999. $00021962009100010007 x$

Marschner H (2002) Nutrient availability in soils. Mineral Nutrition of Higher Plants. Academic Press, San Diego

McDowell RW, Catto W, McDowell NLS (2020) The mitigation of phosphorus losses from a water-repellent soil used for grazed dairy farming. Geoderma 362:114125. https://doi.org/10.1016/j.geoderma.2019.114125

McGhie DA, Posner AM (1980) Water repellence of a heavy textured Western Australian surface soil. Soil Res 18:309-323. https://doi.org/10.1071/SR9800309

Morales VL, Parlange JY, Steenhuis TS (2010) Are preferential flow paths perpetuated by microbial activity in the soil matrix? A review. J Hydrol 393:29-36. https://doi. org/10.1016/j.jhydrol.2009.12.048

Morley CP, Mainwaring KA, Doerr SH, Douglas P, Llewellyn CT, Dekker LW (2005) Organic compounds at different depths in a sandy soil and their role in water repellency. Soil Res 43:239-249. https://doi.org/10. 1071/SR04094

Müller K, Mason K, Strozzi AG, Simpson R, Komatsu T, Kawamoto K, Clothier B (2018) Runoff and nutrient loss from a water-repellent soil. Geoderma 322:28-37. https://doi.org/10.1016/j.geoderma.2018.02.019

Naeem HA, MacRitchie F (2003) Effect of sulphur nutrition on agronomic and quality attributes of wheat. In: YP Abrol, A Ahmad (eds) Sulphur in Plants. Springer, Dordrecht.

Palta J, Chen X, Milroy S, Rebetzke G, Dreccer M, Watt M (2011) Large root systems: Are they useful in adapting wheat to dry environments? Funct Plant Biol 38:347354. https://doi.org/10.1071/FP11031

Pang J, Palta JA, Rebetzke GJ, Milroy SP (2014) Wheat genotypes with high early vigour accumulate more nitrogen and have higher photosynthetic nitrogen use efficiency during early growth. Funct Plant Biol 41:215-222. https://doi.org/10.1071/FP13143

Rayment GE, Lyons DJ (2011) Soil Chemical Methods: Australasia. CSIRO Publishing, Victoria

Reuter DJ, Robinson JB (1997) Plant Analysis: An Interpretation Manual. CSIRO Publishing, Victoria

Ritsema CJ, Dekker LW (1994) How water moves in a water repellent sandy soil: 2 . Dynamics of fingered flow. Water Resour Res 30:2519-2531. https://doi.org/10.1029/ 94WR00750

Robinson D (1994) The responses of plants to non-uniform supplies of nutrients. New Phytol 127:635-674. https:// doi.org/10.1111/j.1469-8137.1994.tb02969.x

Roper MM, Davies SL, Blackwell PS, Hall DJM, Bakker DM, Jongepier R, Ward PR (2015) Management options for water-repellent soils in Australian dryland agriculture. Soil Res 53:786-806. https://doi.org/10.1071/SR14330

Rose TJ, Rengel Z, Ma Q, Bowden JW (2009) Crop species differ in root plasticity response to localised $\mathrm{P}$ supply. $\mathrm{J}$ 
Plant Nutr Soil Sci 172:360-368. https://doi.org/10.1002/ jpln.200800031

Ruthrof KX, Hopkins AJM, Danks M, O'Hara G, Bell R, Henry D, Standish R, Tibbett M, Howieson J, Burgess T, Harper R (2019) Rethinking soil water repellency and its management. Plant Ecol 220:977-984. https://doi.org/10. 1007/s11258-019-00967-4

Rye CF, Smettem KRJ (2017) The effect of water repellent soil surface layers on preferential flow and bare soil evaporation. Geoderma 289:142-149. https://doi.org/10.1016/j. geoderma.2016.11.032

Salem MA, Al-Zayadneh W, Cheruth AJ (2010) Water conservation and management with hydrophobic encapsulation of sand. Water Resour Manag 24:2237-2246. https://doi. org/10.1007/s11269-009-9549-4

Sarkar D, Baishya LK (2017) Nutrient use efficiency. In: M Naeem, AA Ansari, SS Gill (eds) Essential Plant Nutrients: Uptake, Use Efficiency, and Management. Springer, Cham

Scanlon TT, Doncon G (2020) Rain, rain, gone away: decreased growing-season rainfall for the dryland cropping region of the south-west of Western Australia. Crop Pasture Sci 71:128-133. https://doi.org/10.1071/CP19294

Seyfried MS, Rao PSC (1987) Solute transport in undisturbed columns of an aggregated tropical soil: preferential flow effects. Soil Sci Soc Am J 51:1434-1444. https://doi.org/ 10.2136/sssaj1987.03615995005100060008x

Shakesby RA, Doerr SH, Walsh RPD (2000) The erosional impact of soil hydrophobicity: current problems and future research directions. J Hydrol 231-232:178-191. https://doi.org/10.1016/S0022-1694(00)00193-1

Shao HB, Chu LY, Jaleel CA, Zhao CX (2008) Water-deficit stress-induced anatomical changes in higher plants. C R Biologies 331:215-225. https://doi.org/10.1016/j.crvi. 2008.01.002

Simmonds B, McDowell RW, Condron LM (2016) The effect of soil moisture extremes on the pathways and forms of phosphorus lost in runoff from two contrasting soil types. Soil Res 55:19-27. https://doi.org/10.1071/SR15324

Smettem KRJ, Rye C, Henry DJ, Sochacki SJ, Harper RJ (2021) Soil water repellency and the five spheres of influence: A review of mechanisms, measurement and ecological implications. Sci Total Environ 787:147429. https://doi.org/10.1016/j.scitotenv.2021.147429

Suppiah R, Hennessy KJ (1998) Trends in total rainfall, heavy rain events and number of dry days in Australia, 19101990. Int J Climatol 18:1141-1164. https://doi.org/10. 1002/(SICI) 1097-0088(199808)18:10\%3c1141::AIDJOC286\%3e3.0.CO;2-P
Trapeznikov VK, Ivanov II, Kudoyarova GR (2003) Effect of heterogeneous distribution of nutrients on root growth, ABA content and drought resistance of wheat plants. Plant Soil 252:207-214. https://doi.org/10.1023/A:10247 34310214

Unkovich M, McBeath T, MacDonald L, Vadakattu G, Llewellyn R, Hall J, Tonkin D, Baldock J (2015) Management of water repellent sands in the Southern cropping region. Report for GRDC. Commonwealth Scientific and Industrial Research Organisation (CSIRO), Australia.

van der Paauw F (1962) Effect of winter rainfall on the amount of nitrogen available to crops. Plant Soil 16:361-380

van Gool D (2016) Identifying soil constraints that limit wheat yield in the south-west of Western Australia. Report RMTR 399. Department of Agriculture and Food Western Australia, Perth, Western Australia.

Walden LL, Harper RJ, Mendham DS, Henry DJ, Fontaine JB (2015) Eucalyptus reforestation induces soil water repellency. Soil Res 53:168-177. https://doi.org/10.1071/ SR13339

Wang Z, Wu QJ, Wu L, Ritsema CJ, Dekker LW, Feyen J (2000) Effects of soil water repellency on infiltration rate and flow instability. J Hydrol 231-232:265-276. https:// doi.org/10.1016/S0022-1694(00)00200-6

Weaver JE (1926) Root Development of Field Crops. McGrawHill Book Company New York.

Witter JV, Jungerius PD, ten Harkel MJ (1991) Modelling water erosion and the impact of water repellency. CATENA 18:115-124. https://doi.org/10.1016/03418162(91)90011-L

Yu P, White PJ, Hochholdinger F, Li C (2014) Phenotypic plasticity of the maize root system in response to heterogeneous nitrogen availability. Planta 240:667-678. https://doi. org/10.1007/s00425-014-2150-y

Zhao FJ, Withers PJA, Evans EJ, Monaghan J, Salmon SE, Shewry PR, McGrath SP (1997) Sulphur nutrition: An important factor for the quality of wheat and rapeseed. Soil Sci Plant Nutr 43:1137-1142. https://doi.org/10. 1080/00380768.1997.11863731

Publisher's note Springer Nature remains neutral with regard to jurisdictional claims in published maps and institutional affiliations. 